\author{
ACTA MYCOLOGICA \\ Vol. 47 (1): 97-107 \\ 2012
}

\title{
Myxomycetes of the Lipówka reserve in the Niepołomice Old Growth Forest (S Poland)
}

\author{
ANNA DROZDOWICZ ${ }^{1}$, POLA SZOLC ${ }^{2}$, ANNA BOCHYNEK ${ }^{1}$, and AGNIESZKA SALAMAGA \\ ${ }^{1}$ Institute of Botany, Jagiellonian University, Kopernika 27 \\ PL-31-501 Kraków, anna.drozdowicz@uj.edu.pl \\ 214th Silesian Insurgents' Regiment School Complex, Szkolna 1 \\ PL-44-300 Wodzisław Śląski, pszolc@poczta.onet.pl
}

Drozdowicz A., Szolc P., Bochynek A., Salamaga A.: Myxomycetes of the Lipówka reserve in the Niepołomice Old Growth Forest (S Poland). Acta Mycol. 47 (1): 97-107, 2012.

Fifty eight species and three varieties of slime moulds were collected in the Lipówka reserve in 1999 and 2001. Thirty taxa of slime moulds very rare and rare in Poland were recorded in the reserve, including: Arcyria minuta, A. stipata, Physarum penetrale, P. robustum, and Symphytocarpus flaccidus which are red listed (Drozdowicz et al. 2006).

Key words: slime moulds, lignicolous species, biodiversity

\section{INTRODUCTION}

Myxomycetes are a small group of eukaryotic organisms with approximately 930 species described worldwide (Lado 2005-2012). About two hundred and fifty species have been recorded in Poland (Drozdowicz et al. 2003). Most data comes from national parks and nature reserves in Southern Poland, but in the recent years the interesting investigations were also undertaken in North-East part of the country (Panek, Romański 2010). The Lipówka reserve was selected as the study area on the quantitative and qualitative diversity of the myxomycete biota. 


\section{STUDY AREA}

Situated in the northern part of the Niepołomice Old Growth Forest, the Lipówka reserve was established in 1957 and covers an area of 25.73 ha (Fig.1). The reserve protects a natural, multi-species tree stand 170 to 200 years old. Tilio-Carpinetum stachyetosum sylvaticae, Tilio-Carpinetum typicum, Circaeo-Alnetum and Carici elongatae-Alnetum occur on moist and mesic habitats of the Vistula's alluvial floodplain. The flora of vascular plants comprises 134 species (Denisiuk 1978). This is consistent with the lowland forest flora of moist and shaded habitats. The tree stand in the reserve is formed by Quercus robur, Carpinus betulus, Tilia cordata, and Alnus glutinosa. Pinus sylvestris (planted), Ulmus laevis, and U. minor as well as sporadically Padus avium and Populus tremula occur as accompanying species.

A large amount of dead deciduous wood (logs, fallen trees, trunks and stumps, boughs and branches) was observed on the forest floor (Fig. 2). Bark was piled up in the area, especially around dead trunks of Pinus sylvestris. Thicker layers of litter were recorded in some parts of the reserve. They are potential microhabitats of slime moulds, but there were no information about occurrence of these organisms up to the 1999 .

Macrofungi of Niepołomice Old Growth Forest were studied by Wojewoda $(1978,1979)$ and Komorowska $(1980,1986,1991)$ but the most detailed observations were made in course of the project "Mycological monitoring in European oak forests" over the period 1994-1996 (Wojewoda et al. 1999).

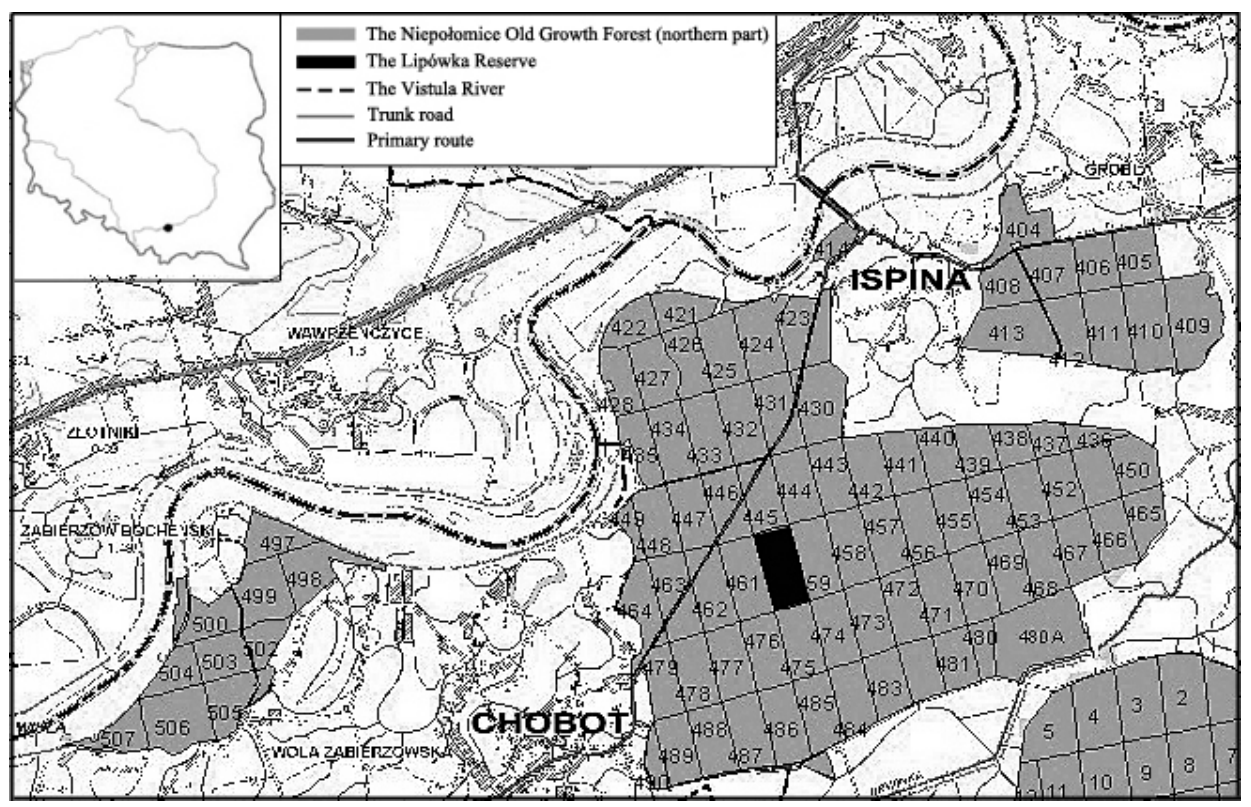

Fig. 1. Geographical position of the Lipówka reserve (source: Nadleśnictwo Niepołomice). 


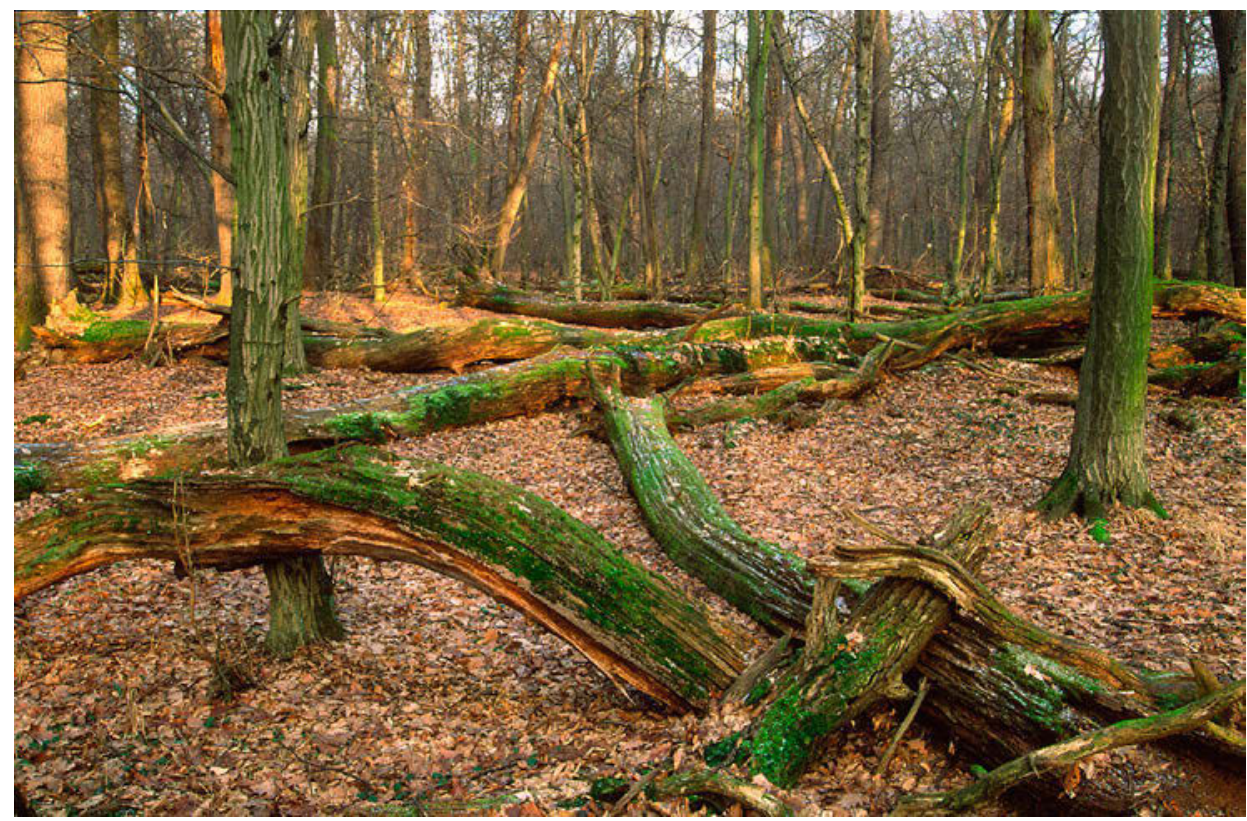

Fig. 2. The „Lipówka” reserve - Tilio-Carpinetum in the early winter (05.01.2003; photo by R\&M Kosińscy).

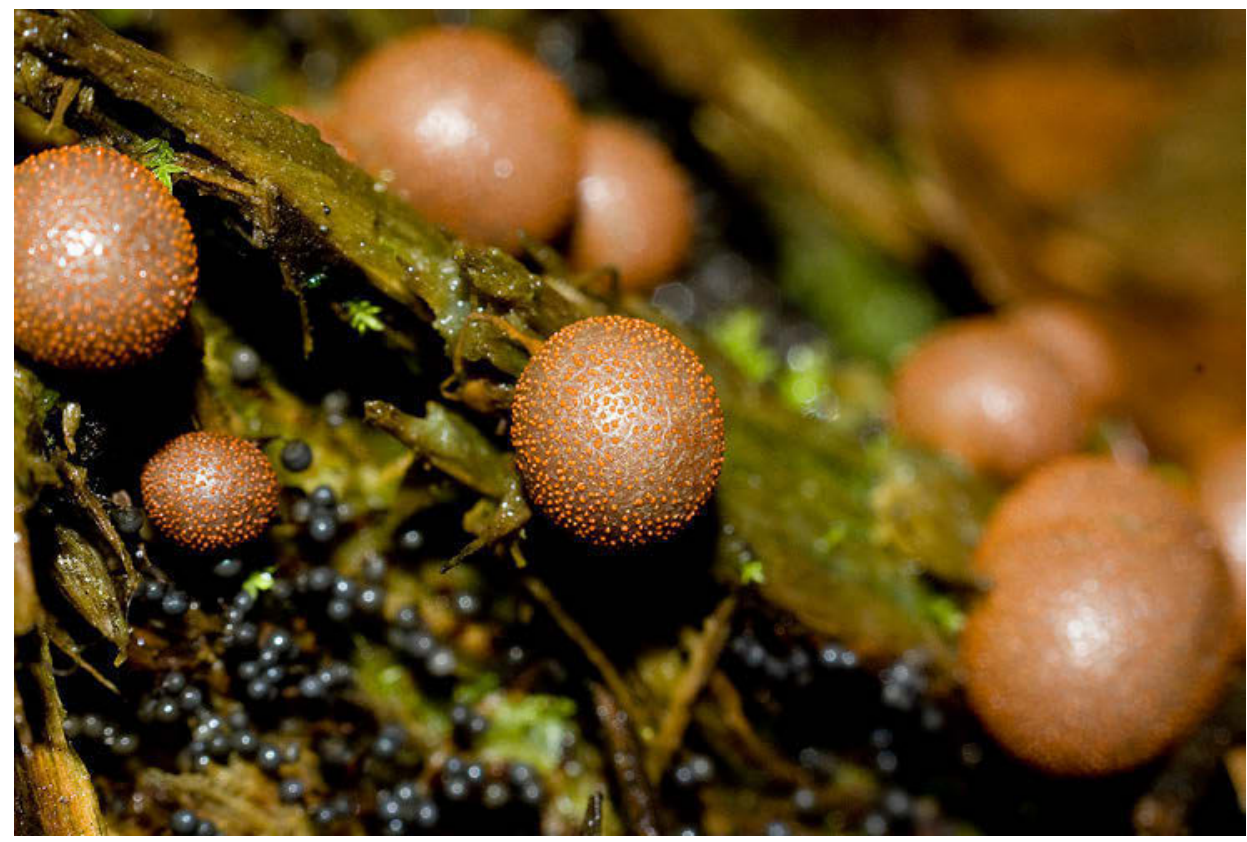

Fig. 3. A common lignicolous slime moulds in the Lipówka reserve.

Lycogala epidendrum (L.) Fr. - immature aethalia and Cribraria sp. - black, globose, immature stalked sporangia (10.08.2010; photo by A. Bochynek). 



\section{MATERIAL AND METHODS}

Research within slime moulds in the Lipówka reserve was carried out from July until November 1999 and from May until November 2001. The route method supplemented with observations of logs and stumps of selected tree species was used. Litter was also examined. Small samples of specimens were collected, i.e., single aethelia or aggregations of free sporangia, recorded at a locality. The substrate type, the collection date and frequency were noted for each taxon. A five-grade scale of the occurrence frequency by Drozdowicz (1992) was used.

The specimens were examined taxonomically using studies by Lister (1925), Krzemieniewska (1960), Martin and Alexopoulos (1969), Nannenga-Bremekamp (1991), Neubert, Nowotny and Baumann (1993, 1995, 2000), Stephenson and Stempen (1994), Lado and Pando (1997), Ing (1999). The nomenclature was adopted after Lado (2005-2012), and vascular plants follows Mirek et al. (2002).

The collections of slime moulds were deposited in the Herbarium of the Institute of Botany, Jagiellonian University (KRA), in the MYXO division.

\section{RESULTS}

Sixty one taxa (58 species and 3 varieties) were identified among the total of 766 specimens collected. The nomenclatural information system of Eumycetozoa (Lado 2005-2012) does not include varieties while most taxonomical studies do. Specimens of typical forms of Ceratiomyxa fruticulosa, Fuligo septica and Physarum viride and their varieties were observed and collected in the Lipówka reserve. They are recorded on the list of slime moulds occurring in the reserve area.

Identified taxa are listed alphabetically and arranged in Table 1, the substrate categories colonised by the species, phenology and category of frequency are given for each taxon. Wood type is marked with an asterisk (*) if this is a new substrate supplementing the data for species reported by Drozdowicz et al. (2003). Based on research in Lipówka reserve, 39 species were noted on a substrate, hitherto not reported from Poland.

As it is indicated in Table 1, twenty two species occurred only on dead wood of lime, hornbeam and oak, two taxa were recorded on coniferous wood. Lignicolous species evidently dominated in the myxomycete biota and formed the most numerous ecological group of slime moulds in the Lipówka reserve. The greatest number of species, i.e. 32 were recorded on deciduous and coniferous trees, especially on logs lying on the forest floor and on logs suspended over drainage ditches. In this group, seven species of Cribraria were recognized in the Lipówka reserve. They occurred, first of all, on dead, deciduous wood. Only one of them, Cribraria macrocarpa was recorded on dead pine wood.

The following species were noted on the bark of living trees: Lycogala epidendrum (Fig. 3) on Pinus sylvestris, Stemonitis fusca on Tilia cordata, Physarum album and $P$. cinereum on Carpinus betulus. It could not be determined whether the presence of 


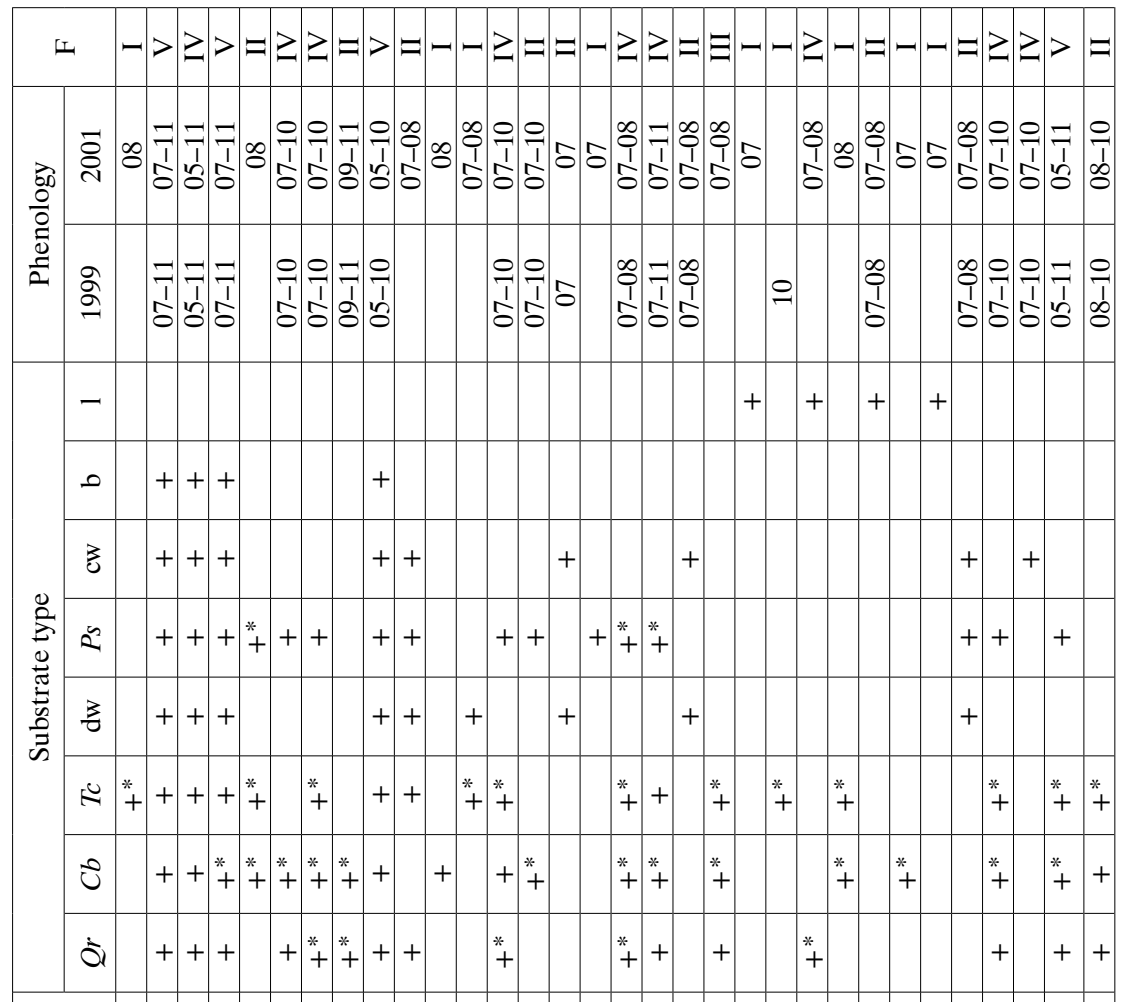

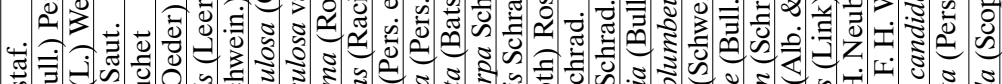

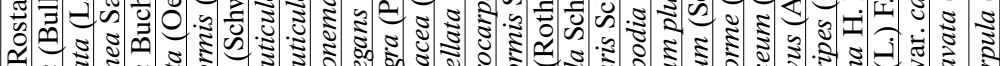

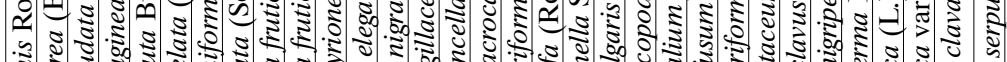

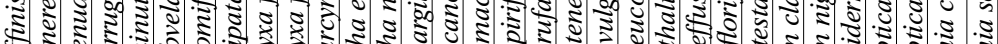

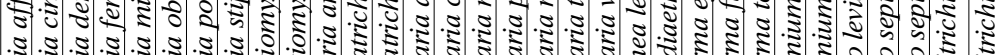
.

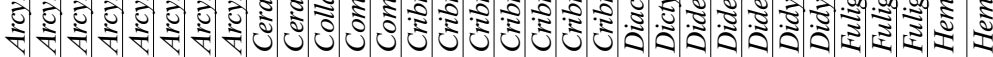

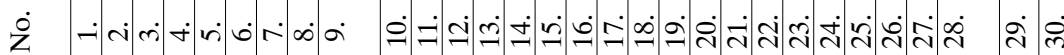




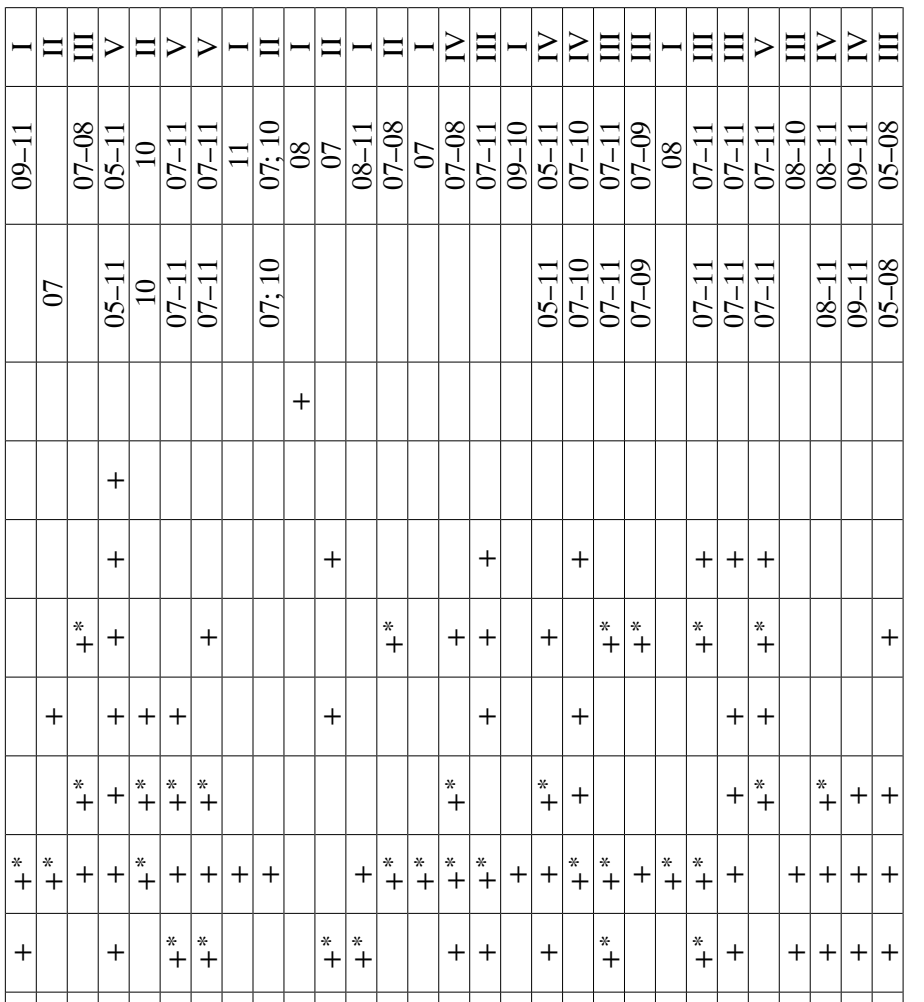

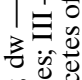

ड़ क्र

记苛

।.

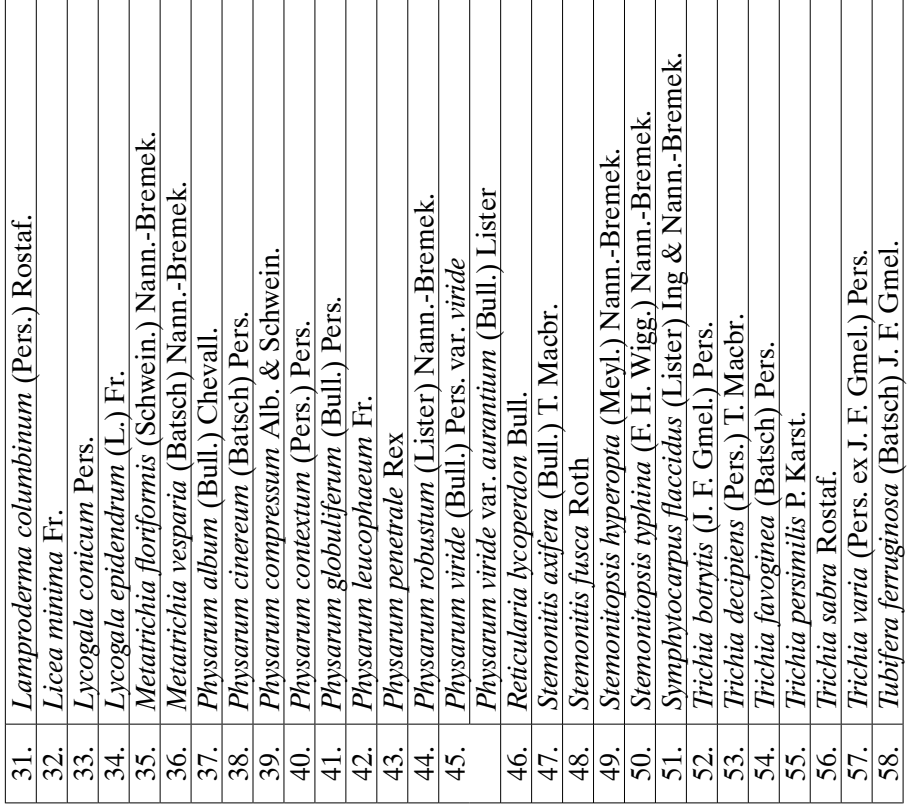

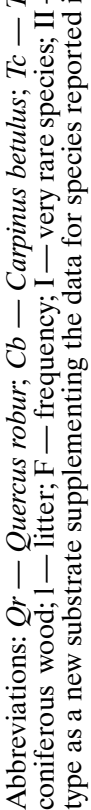




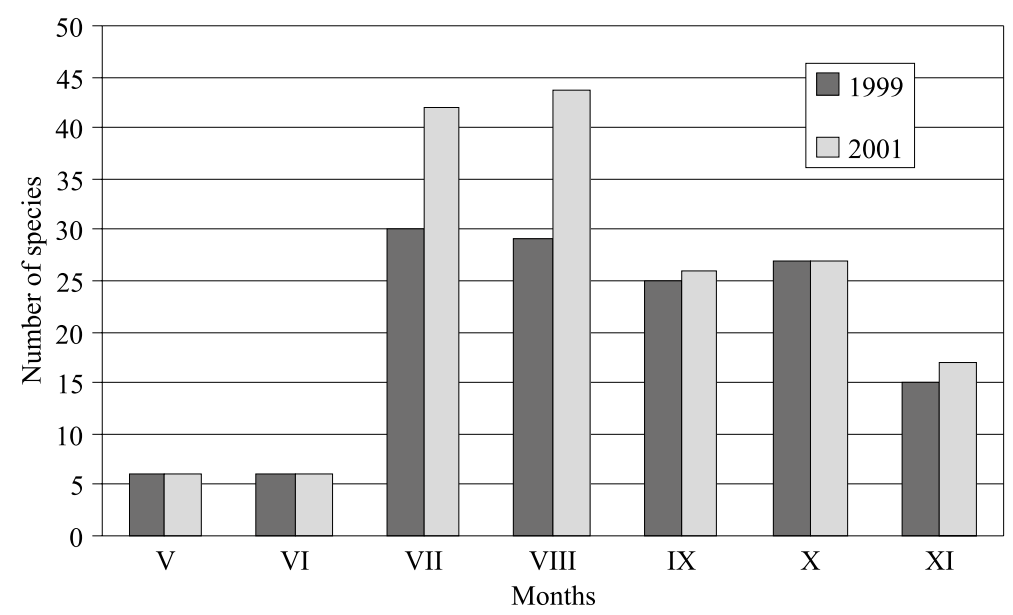

Fig. 4. The occurrence of slime moulds in the Lipówka reserve in 1999 and 2001.

the sporangium of these slime moulds resulted from plasmodium migration from the trunk base or the development of the plasmodium in situ in bark fissures. Sporangia were situated on trunks at a height of $1 \mathrm{~m}$ to $2 \mathrm{~m}$ over the ground surface.

Diachea leucopodia, Diderma testaceum, Didymium nigripes and Physarum contextum were observed on litter, and one species Diderma effusum was recorded on oak wood and litter.

The intensity of the occurrence of individual myxomycete species varied in successive months of the vegetative seasons in 1999 and 2001 (Fig. 4). Specimens of species preserved from the previous vegetative season were mostly collected in May 2001, i.e., Hemitrichia clavata, Metatrichia floriformis and Trichia favoginea. The development of Ceratiomyxa fruticulosa and Lycogala epidendrum was also observed at that time.

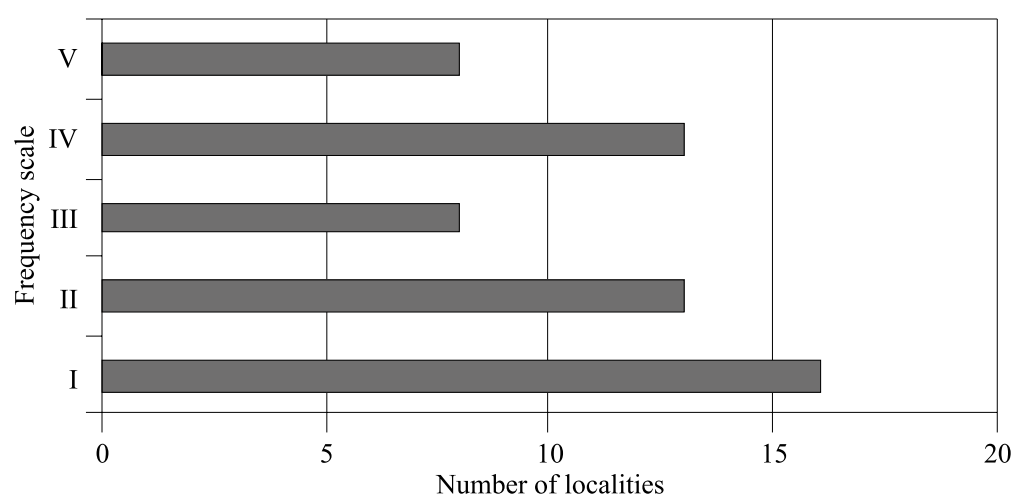

Fig. 5. The frequency of slime moulds in the Lipówka reserve:

I - very rare: 1-2 localities; II - rare: 3-5 loc.; III - frequent: 6-10 loc.; IV - very frequent: 11-29 loc.; V - common: > 30 loc. 
The occurrence maxima of sporangia were observed in the Lipówka reserve in July and August in 1999 and 2001 when sporangia of up to 41 myxomycete species were recorded. Sporangia of 29 species were observed in September. Mature sporangia were also found in November. A considerable temperature drop inhibited plasmodium activity.

Two groups of taxa distinguished basing on the observations of slime moulds in two vegetative seasons with reference to the frequency scale (Fig. 5), were the most interesting: the groups I and II. Very rare myxomycetes (16 species) included species such as Comatricha elegans, Physarum robustum and Symphytocarpus flaccidus, rare slime moulds (13 species and 1 variety) included Arcyria minuta, A. stipata and Physarum penetrale. A total of 30 very rare and rare species were recorded in the reserve, and among them: Arcyria minuta, A. stipata, Physarum penetrale, P. robustum and Symphytocarpus flaccidus are rare in Poland according to the red list (Drozdowicz et al. 2006).

Lycogala conicum, Stemonitopsis hyperopta and other six species were frequent. Thirteen very frequent species were observed, including a.o.: Arcyria pomiformis, Cribraria piriformis and Diderma effusum. A total of eight species common in the reserve were found, including Arcyria ferruginea, Ceratiomyxa fruticulosa and Lycogala epidendrum.

\section{DISCUSSION}

Studies on slime moulds in the Lipówka reserve were conducted only in two vegetative seasons but their results are of great value as the myxomycete biota in the reserve had not been examined previously. Species rare in Poland were recorded, including Arcyria minuta, A. stipata, Physarum penetrale, P. robustum and Symphytocarpus flaccidus (Drozdowicz et al. 2006). The red list category of Arcyria stipata and Symphytocarpus flaccidus will probably change as the sites recorded in the Lipówka reserve are new localities of these species in Poland. New data on the colonisation of dead deciduous wood by individual myxomycete species collected in the present study expand the list of substrate types given in Myxomycetes of Poland (Drozdowicz et al. 2003).

The results of observations of myxomycetes in the Lipówka reserve confirm that there is no direct correlation between the occurrence of slime moulds and the plant community type. However, a multi-species tree stand with a high contribution of oak, hornbeam and lime indirectly influences the biota of myxomycetes. A variety of microhabitats of slime moulds have developed in the strictly protected part of reserve during the natural process of accumulation of high amounts of dead wood, mostly deciduous wood, on the forest floor. The degree of wood decomposition, the presence of bryophytes covering differently various parts of wood surfaces or bark fragments, often preserved on logs, branches and stumps, and the position of logs and branches on the soil surfaces affected the moisture content of substrata. Lignicolous taxa prevailed in the myxomycete biota. Only four species: Diachea leucopodia, Diderma testaceum, Didymium nigripes, Physarum contextum were recorded exclusively on the litter formed 
by fallen leaves, fruits and seeds, cones, small twigs and bark fragments. Sporangia of Lycogala epidendrum, Stemonitis fusca, Physarum album and $P$. cinereum were observed on the bark of living trees; however, the species are not typical of corticolous myxomycetes (Ing 1994). In the event of Cribraria genus Krzemieniewska (1960) suggested that Cribraria spp., were most often found on coniferous wood, however the results of investigation in the Lipówka reserve were different - much more species of Cribraria were found on deciduous than on coniferous wood.

Slime moulds have been sometimes collected together with macromycetes during field studies in different forest complexes in Poland. In Central Poland slime

Table 2

Comparison of the slime moulds biota of the Lipówka and the Łężczok reserves

\begin{tabular}{|c|c|}
\hline \multicolumn{2}{|c|}{ Taxa in both reserves } \\
\hline Arcyria cinerea & Lycogala conicum \\
\hline Arcyria denudata & Lycogala epidendrum \\
\hline Arcyria ferruginea & Metatrichia vesparia \\
\hline Arcyria obvelata & Physarum album \\
\hline Arcyria pomiformis & Physarum cinereum \\
\hline Arcyria stipata & Physarum leucophaeum \\
\hline Ceratiomyxa fruticulosa var. fruticulosa & Physarum viride var. viride \\
\hline Comatricha nigra & Physarum viride var. aurantium \\
\hline Cribraria piriformis & Reticularia lycoperdon \\
\hline Cribraria rufa & Stemonitis axifera \\
\hline Cribraria vulgaris & Stemonitis fusca \\
\hline Diachea leucopodia & Stemonitopsis typhina \\
\hline Dictydiaethalium plumbeum & Trichia botrytis \\
\hline Diderma effusum & Trichia favoginea \\
\hline Diderma floriforme & Trichia persimilis \\
\hline Fuligo leviderma & Trichia scabra \\
\hline Fuligo septica var. septica & Trichia varia \\
\hline Hemitrichia clavata & Tubifera ferruginosa \\
\hline \multirow{2}{*}{\multicolumn{2}{|c|}{ Hemitrichia serpula }} \\
\hline & \\
\hline Arcyria affinis & Fuligo septica var. candida \\
\hline Arcyria minuta & Lamproderma columbinum \\
\hline Ceratiomyxa fruticulosa var. porioides & Licea minima \\
\hline Collaria arcyrionema & Metatrichia floriformis \\
\hline Comatricha elegans & Physarum compressum \\
\hline Cribraria argillacea & Physarum contextum \\
\hline Cribraria cancellata & Physarum globuliferum \\
\hline Cribraria macrocarpa & Physarum penetrale \\
\hline Cribraria tenella & Physarum robustum \\
\hline Diderma testaceum & Stemonitopsis hyperopta \\
\hline Didymium clavus & Symphytocarpus flaccidus \\
\hline Didymium nigripes & Trichia decipiens var. decipiens \\
\hline \multicolumn{2}{|c|}{ Only in Łężczok reserve } \\
\hline Arcyria incarnata & Lamproderma arcyrioides \\
\hline Arcyria major & Lycogala exiguum \\
\hline Arcyria oerstedii & Perichaena corticalis \\
\hline Badhamia panicea & Perichaena depressa \\
\hline Brefeldia maxima & Physarum flavicomum \\
\hline Craterium aureum & Physarum pusillum \\
\hline Craterium leucocephalum & Stemonitis flavogenita \\
\hline Diderma deplanatum & Trichia affinis \\
\hline Didymium iridis & Trichia contorta \\
\hline Enerthenema papillatum & Trichia decipiens var. olivacea \\
\hline Fuligo muscorum & \\
\hline
\end{tabular}


moulds were collected in 7 nature reserves in Tilio-Carpinetum and Potentillo albae-Quercetum (Lawrynowicz 1973). This data are included in the list published by Kalinowska-Kucharska (1975). The most thorought investigations of slime moulds in Tilio-Carpinetum concentrated in the area of nature reserve Łężczok (SW Poland) (Stojanowska 1974; Stojanowska, Panek 2002). The forest of this nature reserve comprises 136 ha and consists mainly of Quercus robur, Carpinus betulus, Tilia cordata, Alnus glutinosa, and Ulmus glabra, and some other trees, i.e., Fagus sylvatica, and Picea abies. Research on slime moulds in the Lężczok reserve was conducted between 1967 and 1968, 1996 and 1999 and in 2001.

Thirty six species occur both in Łężczok and Lipówka reserves. Twenty species and one variety were recorded in Łężczok and twenty two species and two varieties were observed in Lipówka. The majority of taxa that occurred in both reserves are widespread and are common in Poland. However, Arcyria stipata, Diderma effusum and $D$. floriforme occur at few localities in Poland. Despite careful observations and a thorough in-field search, many taxa were recorded at single localities while many others were not found et all. The biotas recorded in both reserves are compared in Table 2.

It is difficult to identify specific factors that inhibit the occurrence of individual species. Leocarpus fragilis was not recorded either in the Lipówka reserve or in the Łężczok reserve (Stojanowska, Panek 2002) while it is known to occur in southern Poland (Drozdowicz 1977, 1997). Although L. fragilis may be less numerous in the south than it is in the north of Poland (Panek, Romański 2010), it is recorded quite frequently mostly as a litter-colonising taxon.

\section{CONCLUSIONS}

Dead wood resources, specially deciduous wood and litter, constituted potential microhabitats for myxomycetes in both reserves. However, not only the quality and availability of the substrate is important for their development.

An overview of habitats and slime moulds associated with them worldwide was published in the late $20^{\text {th }}$ century (Ing 1994). According to Ing, research into the occurrence, geographical distribution and relationships among various groups of organisms and slime moulds should be continued. Regional observations of slime moulds, conducted even in small areas, are important for a better understanding of these organisms.

\section{REFERENCES}

Denisiuk Z. 1978. Szata roślinna rezerwatu Lipówka w Puszczy Niepołomickiej. Stud. Nat. A. 17: 87-117. Drozdowicz A. 1977. Myxomycetes of the Władysław Orkan forest reserve at Turbacz in the Gorce Mountains. Zesz. Nauk. Uniw. Jagiellon. Prace Bot. 5: 157-167 (in Polish with English summary).

Drozdowicz A. 1992. Slime moulds (Myxomycetes) of the Ojców National Park. Part. I. Floristic problems. Zesz. Nauk. Uniw. Jagiellon. Prace Bot. 24: 125-145.

Drozdowicz A. 1997. Studies on Myxomycetes in the Pieniny National Park I. New species for the PNP. Acta Mycol. 32 (2): 287-291. 
Drozdowicz A., Ronikier A., Stojanowska W., Panek E. 2003. Myxomycetes of Poland. A checklist. (In:) Z. Mirek (ed.). Biodiversity of Poland. 10. W. Szafer Institute of Botany, Polish Academy of Sciences, Kraków.

Drozdowicz A., Ronikier A., Stojanowska W. 2006. Red list of rare Myxomycetes in Poland. (In:) Z. Mirek, K. Zarzycki, W. Wojewoda, Z. Szeląg (eds). Red list of plants and fungi in Poland. W. Szafer Institute of Botany, Polish Academy of Sciences, Kraków: 91-99.

Ing B. 1994. The phytosociology of myxomycetes. Tansley Reviev No 62. New Phytologist 126: 175-201.

Ing B. 1999. The Myxomycetes of Britain and Ireland. The Richmond Publishing Co. Ltd. Slough, England.

Kalinowska-Kucharska E. 1975. Materiały do flory śluzowców Polski Środkowej. Acta Mycol. 11 (1): 93-99.

Kiszka J. 1978. Porosty rezerwatu Lipówka w Puszczy Niepołomickiej. Stud. Nat. A. 17: 149-158.

Komorowska H. 1980. Mushrooms. (In:) K. Grodzińska (ed.). Acidification of forest environment (Niepołomice Forest) caused by $\mathrm{SO}^{2}$ emissions from steel mills. Institute of Botany, Polish Academy of Sciences, Kraków: 91-98.

Komorowska H. 1986. Onygena equina (Willd.) Pers.: Fr. in Poland. Acta Mycol. 22 (1): 49-52.

Komorowska H. 1991. Tricholomataceae (Agaricales) Puszczy Niepołomickiej. Folia Soc. Sci. Lubl. 30, Biologia 1-2: 55-62.

Krzemieniewska H. 1960. Śluzowce Polski na tle flory śluzowców europejskich. Flora polska. PWN, Warszawa.

Lado C. 2005-2012. An on line nomenclatural information system of Eumycetozoa. http://www.nomen. eumycetoza.com (05.06.2012).

Lado C., Pando F. 1997. Myxomycetes I. Ceratiomyxales, Echinosteliales, Liceales, Trichiales. Flora Mycol. Iberica 2: 1-323.

Ławrynowicz M. 1973. Grzyby wyższe makroskopowe w grądach Polski środkowej. Acta Mycol. 9 (2): 133-204.

Lister A. 1925. A monograph of the Mycetozoa. Ed. 3. London.

Martin G. W., Alexopoulos C. J. 1969. The Myxomycetes. University of Iowa Press, Iowa City.

Mirek Z., Piękoś-Mirek H., Zając A., Zając M. 2002. Flowering plants and pteridophytes of Poland. A checklist. (In:) Z. Mirek (ed.). Biodiversity of Poland. 1. W. Szafer Institute of Botany, Polish Academy of Sciences, Kraków.

Nannenga-Bremekamp N. E. 1991. A guide to temperate myxomycetes. Biopress Limited, Bristol.

Neubert H., Nowotny W., Baumann K. 1993. Die Myxomyceten Deutschlands und des angrenzenden Alpenraumes unter besonderer Berücksichtigung Österreichs. 1. Karlheinz Baumann Verlag, Gomaringen.

Neubert H., Nowotny W., Baumann K. 1995. Die Myxomyceten Deutschlands und des angrenzenden Alpenraumes unter besonderer Berücksichtigung Österreichs. 2. Karlheinz Baumann Verlag, Gomaringen.

Neubert H., Nowotny W., Baumann K. 2000. Die Myxomyceten Deutschlands und des angrenzenden Alpenraumes unter besonderer Berücksichtigung Österreichs. 3. Karlheinz Baumann Verlag, Gomaringen.

Panek E., Romański M. 2010. Śluzowce Myxomycetes. (In:): L. Krzysztofiak (ed.). Śluzowce Myxomycetes, grzyby Fungi i mszaki Bryophyta Wigierskiego Parku Narodowego. Przyroda Wigierskiego Parku Narodowego, seria naukowa. Stowarzyszenie „Człowiek i Przyroda”. Suwałki: 9-85.

Stephenson S. L., Stempen H. 1994. Myxomycetes. A handbook of slime molds. Timber Press, Portland, Oregon (Reprint 2000).

Stojanowska W. 1974. Flora śluzowców kilku rezerwatów leśnych Opolszczyzny. Fragm. Flor. Geobot. 20 (2): 283-293.

Stojanowska W., Panek E. 2002. Changes in the myxomycete biota of the „Lężczok” nature reserve near Racibórz (SW Poland). Acta Mycol. 37 (1/2): 13-28.

Wojewoda W. 1978. Grzyby wielkoowocnikowe rezerwatu Lipówka w Puszczy Niepołomickiej. Stud. Nat. A. $17: 159-168$.

Wojewoda W. 1979. Rozmieszczenie geograficzne grzybów tremelloidalnych w Polsce. Acta Mycol. 15 (1): 75-144.

Wojewoda W., Heinrich Z., Komorowska H. 1999. Macromycetes of oak hornbean woods in the Niepołomice Forest near Kraków (S Poland) monitoring studies. Acta Mycol. 34 (2): 201-266. 


\section{Śluzowce rezerwatu Lipówka w Puszczy Niepołomickiej (Południowa Polska)}

\section{Streszczenie}

Rezerwat Lipówka został utworzony w 1957 roku, dla zachowania starodrzewu Tilio-Carpinetum stachyetosum sylvaticae, Tilio-Carpinetum typicum, Circaeo-Alnetum oraz Carici elongataeAlnetum. Uroczysko jest położone w północnej części Puszczy Niepołomickiej i zajmuje powierzchnię 25,73 ha (Ryc.1, 2). Na terenie rezerwatu Lipówka badano śluzowce w okresie od lipca do listopada 1999 roku oraz od maja do listopada 2001 roku. Stwierdzono występowanie 61 taksonów (58 gatunków i 3 odmiany) (Tab. 1). Większość śluzowców zanotowano na kłodach zarówno drzew liściastych, jak i iglastych (32 taksony). Na kłodach, pniakach, konarach i drobnych fragmentach martwego drewna drzew liściastych odnotowano 22 taksony, tylko 2 taksony występowały na drewnie drzew iglastych. Gatunki: Diachea leucopodia, Diderma testaceum, Didymium nigripes, Physarum contextum stwierdzono na ściółce. Natomiast zarodnie Diderma effusum zostały znalezione na martwym drewnie dębowym oraz na ściółce.

Śluzowce rozwijały się z różną intensywnością, a maksimum pojawów zaznaczyło się w lipcu i sierpniu (Ryc. 4). Odnotowano 29 taksonów bardzo rzadkich i rzadkich na obszarze uroczyska (Ryc. 5), wśród których do gatunków umieszczonych na Czerwonej liście śluzowców rzadkich w Polsce należą: Arcyria minuta, A. stipata, Physarum penetrale, $P$. robustum oraz Symphytocarpus flaccidus (Drozdowicz et al. 2006).

W Polsce jednym z najlepiej opracowanych pod względem bioty Myxomycetes jest rezerwat Łężczok (Stojanowska 1974; Stojanowska, Panek 2002), w którym lasy zajmują 136 ha. Jest to więc znacznie większy obszar niż uroczyska Lipówka, jednakże zaznacza się podobieństwo zbiorowisk leśnych wymienionych terenów. W rezerwacie Łężczok badania nad śluzowcami przeprowadzono w latach 1967-68, 1996-99 oraz w 2001 roku.

Mimo opisanych różnic pod względem wielkości obszaru oraz długości okresów prowadzonych badań nad zróżnicowaniem gatunkowym śluzowców, dokonano porównania bioty śluzowców rezerwatów Łężczok i Lipówka (Tab. 2). Lista gatunków wspólnych obejmuje 33 gatunki i 4 odmiany, natomiast tylko na obszarze rezerwatu Łężczok znaleziono 20 gatunki i 1 odmianę, a w uroczysku Lipówka 21gat. i 3 odmiany. Większość gatunków wspólnych, zebranych w obu rezerwatach, należy do szeroko rozpowszechnionych i pospolitych na terenie Polski np. Lycogala epidendrum (Ryc. 3). 